\title{
STUDENTS AND SUPERINTENDENTS: FROM "FAMILY STYLE" TO MORAL AND POLITICAL SUPERVISION (BASED ON MATERIALS OF PEDAGOGICAL INSTITUTE AND ST. PETERSBURG UNIVERSITY OF 1800s - 1850s) ${ }^{1}$
}

\author{
Ksenia S. Kazakova \\ Barents Centre of the Humanities, FRC "Kola Science Centre of the Russian Academy of Sciences", \\ Apatity, Russian Federation
}

Tatyana N. Zhukovskaya

St. Petersburg University, Saint Petersburg, Russian Federation

\begin{abstract}
Introduction. The authors attempt to trace the evolution of relations between students and superintendents based on archival materials of Pedagogical Institute and St. Petersburg University. Methods. The research is carried out within the framework of the systems approach using historical methods to determine the specifics of the power relations in Russian universities in the first half of the $19^{\text {th }}$ century. Analysis and results. University relationships were changed under the influence of social and political factors, the evolution of the organizational foundations of the university. The relations of students and a superintendent, who was initially chosen from professors, were of a "patriarchal" nature, and the small size of the university community and its isolation from the urban life of Saint Petersburg contributed to the design of a special "family style" of communication. With the increase in the number of students, it becomes necessary to clarify the legal boundaries of student freedom and strengthen police supervision. A detailed system of norms and prohibitions was legislated, and supervision of its implementation was entrusted to a superintendent, who was elected from civilian or military officials. Excessive strengthening of disciplinary supervision of students ended in all sorts of conflicts between students and superintendents.

Key words: student, superintendent, "family style", police supervision, St. Petersburg University, social history of universities, ethics of academic corporation.

Citation. Kazakova K.S., Zhukovskaya T.N. Students and Superintendents: From "Family Style" to Moral and Political Supervision (Based on Materials of Pedagogical Institute and St. Petersburg University of 1800s - 1850s). Vestnik Volgogradskogo gosudarstvennogo universiteta. Seriya 4. Istoriya. Regionovedenie. Mezhdunarodnye otnosheniya [Science Journal of Volgograd State University. History. Area Studies. International Relations], 2020, vol. 25, no. 2, pp. 68-79. (in Russian). DOI: https://doi.org/10.15688/jvolsu4.2020.2.5
\end{abstract}

\section{СТУДЕНТЫ И ИНСПЕКТОРЫ: ОТ «СЕМЕЙНОГО СТИЛЯ» К НРАВСТВЕННО-ПОЛИТИЧЕСКОМУ НАДЗОРУ (НА МАТЕРИАЛАХ ПЕДАГОГИЧЕСКОГО ИНСТИТУТА И ПЕТЕРБУРГСКОГО УНИВЕРСИТЕТА 1800-1850-х ГГ.) ${ }^{1}$}

\section{Ксения Сергеевна Казакова}

Центр гуманитарных проблем Баренц региона ФИЦ «Кольский научный центр Российской академии наук», г. Апатиты, Российская Федерация 


\section{Татьяна Николаевна Жуковская}

Санкт-Петербургский государственный университет, г. Санкт-Петербург, Российская Федерация

Аннотация. Введение. В дореформенной России отношения внугри университетского сообщества строились и изменялись под воздействием общественно-политических факторов, эволюции организационных основ университета, изменений состава его профессоров и учащихся. На основе архивных материалов Педагогического института и Петербургского университета предпринята попытка проследить эволюцию системы университетского надзора и взаимодействия между студентами и инспекторами. Методы. Исследование базируется на представлении об университете как сообществе, коммуникативные практики внутри которого регулируются не только законодательством, но и академическими традициями, а также зависят от численности и структуры самого сообщества. Это позволило показать специфику властных отношений между студенчеством и инспекцией в дореформенном Петербургском университете. Соединяя институциональный подход к описанию университета с наблюдениями представителей культурно-антропологического направления университетских исследований, авторы обращают внимание на особенности и этапы трансформации патриархального стиля университетских властных отношений в модерный (бюрократический) стиль. Анализ $u$ результаты. В первой четверти XIX в., когда университетские традиции и академическая культура в России только складывались, университетским советам было дано право самим регламентировать дисциплинарные правила для воспитанников университета, а также определять границу между нормой и проступком. Первоначально отношения студентов и инспекторов носили «патриархальный» характер, а малочисленность университетского сообщества и его изолированность от жизни столицы содействовали оформлению особого «семейного стиля» взаимоотношений. С увеличением числа студентов во всех российских университетах возникает необходимость уточнения правовых норм и границ студенческой свободы, а также усиления полицейского надзора. Согласно университетскому Уставу 1835 г., право определять критерии нравственности студента стало прерогативой государства. Была законодательно закреплена детализированная система норм и запретов, надзор за исполнением которой был возложена на инспектора, избиравшегося из гражданских или военных чиновников, а не из преподавателей, как прежде. Чрезмерное усиление дисциплинарного надзора за учащимися заканчивалось разного рода конфликтами между студентами и инспекторами. Особенности внутриуниверситетских административных и социальных коммуникаций на материалах Педагогического института, учрежденного в 1804 г. как «отделение» будущего университета, рассмотрены Т.Н. Жуковской. К.С. Казакова проанализировала правовые нормы и дисциплинарные практики на этапе трансформации патриархальных университетских отношений в модерные.

Ключевые слова: студент, инспектор, «семейный стиль», полицейский надзор, Петербургский университет, социальная история университетов, этика академической корпорации.

Цитирование. Казакова К. С., Жуковская Т. Н. Студенты и инспекторы: от «семейного стиля» к нравственно-политическому надзору (на материалах Педагогического института и Петербургского университета 1800-1850-х гг.) // Вестник Волгоградского государственного университета. Серия 4, История. Регионоведение. Международные отношения. - 2020. - Т. 25, № 2. - C. 68-79. - DOI: https://doi.org/10.15688/jvolsu4.2020.2.5

Введение. Актуальность изучения истории российской высшей школы обусловлена возрастанием роли знания в современном мире и внимания к условиям его производства. Задачей университетов в настоящее время является не только профессиональная подготовка, но и формирование социальной ответственности как интегративного качества личности выпускника. Миссия социального проектирования и стремление воспитать в студенте качества «просвещенного» человека и гражданина была свойственна и дореформенным университетам.

Не менее актуален вопрос о соотнесении поведения университетского человека
XIX в., будь то профессор или студент, с этикой определенной социокультурной группы («ученого сословия») и в то же время с бюрократическими требованиями, имеющими значение для государственного служащего в настоящем или будущем. Администрация университетов Российской империи в первой половине XIX в. осуществляла постоянный контроль за соблюдением членами «ученого сословия» дисциплинарных и этических норм, а профессора рассматривали себя в отношении студентов in loco parentis (вместо родителей) и, соответственно, занимались не только обучением, но и воспитанием студентов [3, с. 199]. Под воспитанием понималось фор- 
мирование политической благонадежности и общественной нравственности. Контроль за соблюдением учащимися дисциплинарных норм был возложен на университетскую инспекцию. Анализ социальных связей и отношений студенчества и инспекторов позволяет проследить в исторической ретроспективе трансформацию академического быта, властных отношений студентов, профессоров и администрации, а также этапы формирования корпоративной этики «ученого сословия».

Дискуссия. В современных university studies прослеживается смещение интереса от политико-административной истории университетов к социальной. Не менее интересны подходы представителей культурно-антропологического направления Е.А. Вишленковой [4], К.А. Ильиной [5], И.П. Кулаковой [10] и др., позволяющие корректировать понимание границ применения университетского законодательства и локальных особенностей университетских сообществ в Москве, Казани, Харькове. В этих исследованиях, в частности, предложено понятие «семейного стиля», свойственного ранней истории университетов, которому соответствовали отношения профессоров к студентам как младшим членам семьи [4, с. 55]. Этот патриархальный тип отношений был вообще характерной чертой малочисленных и довольно замкнутых университетских сообществ в 1760 -х - начала 1830 -х годов. В XVIII в. профессора Московского университета, следуя духу Просвещения, брали на себя «родительские обязанности, в первую очередь - защиту студента-разночинца в период обучения, его социализацию и определенную поддержку после окончания учебы» [10, c. 205].

Ранняя история университетов Российской империи рассматривается в контексте адаптации европейских образовательных традиций («университетской идеи») на русской почве [1]. Российская модель университета выстраивалась «сверху» путем соединения нескольких национальных моделей и собственно российских особенностей бюрократических и властных отношений. Она подчиняла деятельность университетского сообщества целям и условиям, установленным государством, и в то же время определяла тип социальных взаимоотношений внутри университета.
Методы и материалы. Исследование базируется на представлении об университете как сообществе, отношения внутри которого регулируются не только законодательством, но и академическими традициями, а также зависят от численности и структуры самого сообщества. Этот ракурс позволяет интерпретировать особенности властных отношений между студенчеством и инспекцией в дореформенном Петербургском университете как путь от самоорганизации по модели «просвещенного» семейства к постепенному подчинению государственной установке на упорядочение и всестороннюю регламентацию не только учебной, но и внеакадемической активности студента. Соединяя институциональный подход к описанию университета с наблюдениями представителей культурноантропологического направления университетских исследований, авторы обращают внимание на особенности и этапы трансформации патриархального стиля университетских властных отношений в модерный (бюрократический) стиль. Правовое положение студента и границы его академической и личной свободы являются основным предметом описания.

В основу исследования положено ведомственное и университетское делопроизводство, в том числе архив Педагогического института в Петербурге, существовавшего в 1804-1816 гг. как «отделение университета», законодательные акты и ведомственные распоряжения, мемуары универсантов. Комплекс архивных дел о студентах, их проступках и наказаниях за нарушение дисциплинарных норм, дел о нравственной и политической неблагонадежности позволяет проследить оформление правовых рамок пребывания студента в университете, изменение образа студента в глазах власти, университетской администрации и общества, а также описать способы организации внутреннего и внешнего (полицейского) надзора и его эффективность. В работе использовались документы фонда Педагогического института и Петербургского университета (ф. 13, 14 Центрального государственного исторического архива в Санкт-Петербурге), которые представляют собой оформленные свидетельства различных «происшествий», выходящих за рамки обыденного течения университетской жизни. В де- 
лопроизводстве Педагогического института сохранились рапорты профессоров-инспекторов о состоянии института за первые 5-7 лет его существования, в которых дается подробный отчет о нуждах и настроениях студентов, конфликтах, студенческих проступках и их разборе. Эти описания гораздо более адекватны восприятию людьми университетской культуры самих себя, нежели формализованные отчеты по университетам 1830-1840-х годов.

Анализ. Российские университеты, открытые или реформированные в начале XIX в., пытались воспроизвести систему отношений между профессорами и студентами, традиционно существовавшую в европейских университетах в Средние века и Новое время. Эти отношения строились на принципах иерархичности, добровольного подчинения воспитанников старшим членам «ученого сословия». Однако российский студент в отношении к ведомственной и университетской администрации, инспекции и своим преподавателям изначально находился в условиях большей несвободы, нежели его собрат в Геттингене или Галле. Дело в том, что в своей массе студенты немецких и других европейских университетов были свободны в выборе университета, факультета, цикла преподаваемых наук, в праве перемещения из одного университета в другой, поскольку были материально независимы от университета. Система гонораров, вносимых ими за лекции, превращала их в свободных посетителей университета. В то же время практика имматрикуляции (записи в университет при поступлении) означала для этих студентов подчинение условиям обучения, нормам поведения и социального взаимодействия, исторически сложившихся в конкретном университете.

В университете, действовавшем в XVIII в. в составе Академии наук в Петербурге, над студентами был организован контроль, который осуществлял инспектор студентов, избиравшийся из членов Академии. Та же система контроля предусматривалась в университетских уставах 1804 г., она распространялась и на Петербургский Педагогический институт. Число его студентов было незначительным (100-150 человек), при этом абсолютное их большинство принадлежало к категории казеннокоштных. Они обучались в закрытом режиме, проживая компактно в здании института, достаточно изолированно от городского общества столицы [6]. Отношения профессоров института, которые поочередно исполняли обязанности инспекторов, а также младших преподавателей (помощников инспектора) к студентам строились на принципе «отеческой заботы». Профессора были заинтересованы в сохранении контингента студентов, закрывая глаза на «дерзости» учащихся при способности продолжать обучение. «Семейный стиль» взаимоотношений между старшими и младшими членами университетской корпорации был определен дихотомией «воспитатели - воспитуемые», несмотря на то, что средний возраст студентов, среди которых было много выпускников духовных семинарий, превышал 20 лет.

Особенности взаимодействия студентов и профессоров-инспекторов прослеживаются в сохранившихся обстоятельных отчетах последних, которые еженедельно рассматривались Конференцией Педагогического института, а впоследствии Конференцией университета. Инспектора сетовали на отлучки студентов из университета без позволения, пьянство, неповиновение и дерзости [21, л. 16]. Однако эти проступки профессора интерпретировали не как серьезные провинности, а, скорее, как ребяческие шалости и чаще всего не усматривали в них «какой-либо злонамеренной наклонности» [21, л. 16]. Их стремление смягчить описания проступков и предложить для виновных легкие «домашние» наказания также отражает «семейный стиль» раннеуниверситетских отношений. Характеристики студентов в рапортах профессоров весьма разнообразны: «вспыльчив», «ветрен», «ропотлив и неуступчив», что соответствовало нерегламенти рованному языку делопроизводства начала XIX в., еще не выработавшему четких градаций для оценки знаний и поведения.

Осуществлению тотального контроля над казеннокоштными студентами способствовали различные обстоятельства. Так, помощник инспектора из числа младших преподавателей обычно имел квартиру в помещениях университета. Кроме того, в Педагогическом институте был сформирован институт надзирающих «старших» по комнатам, где жили сту- 
денты [14], им помогали дежурные в классах, отмечавшие отсутствующих на лекциях. Верность студенческому братству, выражавшаяся в лояльности к проступкам товарищей со стороны «старших» студентов, ставит под сомнение эффективность данного института $[19$, л. 3]. Однако Устав Главного педагогического института (1816), а также Проект нового устава Петербургского университета, разработанный С.С. Уваровым в 1819 г., попрежнему административно закрепляли принцип самоконтроля студентов [22, с. 77-78].

Меры воздействия на провинившихся студентов также вписывались в «семейный стиль» отношений. Инспектор мог лишить студента стола, запретить ему отлучаться из университета. В качестве мер воздействия использовались облачение в крестьянское платье, принудительные работы в здании университета и телесные наказания. «Розги» как одна из крайних мер применялись в светских и духовных учебных заведениях начала XIX в., в том числе в отношении казенных студентов, вышедших их духовной среды и до окончания университета не имевших определенного сословного статуса. Так, при разрешении конфликта группы студентов с инспектором А.С. Лубкиным в январе 1807 г. Конференция Педагогического института «определила студенту Малиновскому дать 25 ударов розгами, а Приорову $15 »[16$, л. 7]. Наказание розгами по решению Конференции практиковалось и в университетском Благородном пансионе на протяжении всего времени его существования, несмотря на принадлежность большинства его воспитанников к дворянству. Оно могло быть символическим или более «чувствительным», в зависимости от настроения экзекутора, но само по себе воспроизводило «родительское» вмешательство, корректирующее «неблагородное» поведение.

Бывшие семинаристы легко принимали сценарий патриархального воспитания, усердных занятий науками, минимума свободы, аскетического быта. Перспектива выйти по окончании института или университета в педагогическую службу с чином XIV-XII класса, сообщавшим им личное дворянство и общественное уважение, удерживала их от нарушений сурового режима обучения. Но далеко не всех. Если противо- действие студента режиму обучения и надзора становилось демонстративным и повторяющимся, инспекторы, не желая выходить за рамки «семейного стиля» отношений, спешили объяснить эти выходки «умопомешательством» студента и предлагали отправить его на лечение, не изгоняя сочлена из университета [12].

Казус, при котором казенного студента, вышедшего из духовного звания, нельзя было исключить из университета, был юридически разрешен через несколько лет. В апреле 1811 г. издается положение, облегчавшее решение по серьезным дисциплинарным проступкам, «об отсылке в военную службу казенных воспитанников и студентов, как здешнего Педагогического института, так университетов и других высших училищ из духовного звания и разночинцев, развратного поведения и уличенных во вредных преступлениях по исключении их вовсе из упомянутых заведений» [7, с. 70]. С этого времени в институте исчезает практика телесных наказаний, несовместимая с идеологией Просвещения и представлением о высоком статусе члена «ученого сословия». Один из мемуаристов Московского университета сообщает, что со времени вступления в силу данного положения обычай переодевания в крестьянское платье в качестве наказания для казеннокоштных студентов трансформировался в принудительное ношение солдатской шинели и даже обритие головы как у рекрута [2, с. 206]. Подобных свидетельств мы не находим в воспоминаниях о Петербургском университете, что дает повод считать толкование и применение данного указа вариативными в разных учебных заведениях.

Степень наказания студента за проступок, которое назначалось собранием профессоров как судом первой инстанции, зависела не только от тяжести проступка, но и от репутации студента и его формальных и неформальных отношений с профессорами, ректором / директором. Не весьма велика была и дистанция между студентом и попечителем столичного учебного округа. Студент А.В. Никитенко, будучи секретарем попечителя К.М. Бороздина, успешно хлопотал за своего товарища, подвергнувшегося несправедливым придиркам профессора. Заботясь о репутации университета, 
профессора стремились лишний раз не выносить подобные инциденты на суд начальства. Исключение студентов в это время происходило либо по их собственному желанию (для своекоштных), либо по причине болезни или смерти.

Отсутствие фиксированных правил для студентов в первой четверти XIX в. восполнялось отдельными постановлениями и распоряжениями, имеющими прецедентный характер. Эта ситуация порождала различное понимание границ дозволенной свободы самими учащимися и профессорами. Примером служит дело студента Педагогического института Мальцева, которому за неоднократные нарушения режима было запрещено покидать здание института, где учились и жили казенные студенты. Мальцев расценил наказание как несправедливое, возразив инспектору профессору М.Е. Резанову: «Покажите мне закон, а без того я ваших приказов не принимаю» $[12$, л. 11$]$. Инспектор в ответ на это запретил другим студентам одалживать ему верхнюю одежду для выхода из института (свое платье студент заложил еще раньше одному из служителей). Мальцев дерзко заявил, что инспектор «слишком выходит из предметов своей должности» $[12$, л. 11] и не может выносить такие запреты его товарищам. После строгого внушения Мальцев повинился и обещал исправиться, но не сдержал слова и тут же спустил «одолженные у инспектора 5 рублей на биллиардную игру» [12, л. 12 об.]. Отеческая забота инспектора и снисхождение Конференции в этом инциденте не пошли на пользу молодому человеку, который вскоре совсем забросил учебу, бежал из института и был объявлен в розыск.

Необходимость законодательного оформления правил для студентов была очевидна для самих инспекторов и для администрации. Адъюнкт А.С. Лубкин (помощник инспектора) предлагал Конференции профессоров Педагогического института составить «наставление» для студентов, которое висело бы в каждой комнате, «дабы оно, недопущая до уверток, для всякого служило готовым зеркалом» $[19$, л. 2]. В каждом университете на протяжении первой трети XIX в. вырабатывались собственные вариации правил для студентов. В Дерптском университете, студен- ты которого, выходя «из границ благопристойности», часто конфликтовали с жителями города, такие правила были законодательно утверждены уже в 1803 году.

Университеты в первой трети XIX в. брали ответственность за студентов как в университетских стенах, так и вне их. Право «свободы обучения», декларированное во многих немецких университетах со времен А. Гумбольдта, в российских университетах было существенно ограничено. Но в соответствии с буквой уставов 1804 г. и «семейным стилем» отношений внутри сообщества университетам была дарована собственная юрисдикция в отношении своих членов. Студент, как и профессор, за исключением серьезных уголовных преступлений, подлежали суду самой корпорации. Студенты, замешанные в конфликтах с городскими жителями (неплатеж долга, воровство, оскорбление, применение силы и т. п.), в том числе задержанные городской полицией, передавались в университет для разбирательства.

Положение о подчинении учащихся Московского университета городской полиции было введено в 1827 г., что, как полагают исследователи, означало фактическое ограничение «академической свободы» для студентов [23, с. 206]. В следующем году было издано распоряжение, согласно которому своекоштные студенты вне университета оказывались под наблюдением городской полиции [24, стб. 607]. Однако данное распоряжение не отменяло юрисдикции университета над своими членами, а право университетского суда было сохранено и в университетском Уставе 1835 г., хотя на практике почти не использовалось. Стоит отметить, что даже в случае серьезных инцидентов вмешательство попечителя и министра народного просвещения в определение судьбы студента осуществлялось в согласии с характеристиками, данными ему университетом. Исключение составляли дела «политические».

В Петербургском университете прежняя система отношений между учащимися и инспекторами из числа профессоров была нарушена в начале 1820 -х гг. во время попечительства Д.П. Рунича после организованных им репрессий против профессоров, обвиненных в вольнодумстве [11, с. 127-175]. Вслед за этим 
последовал «разбор» студентов, изгоняемых из университета или оставляемых, в зависимости от их успехов и нравственности. Именно Д.П. Рунич, минуя Совет профессоров, направлял инспектору студентов составленные им самим дисциплинарные правила и требовал их выполнения. Директор университета Д.А. Кавелин, отвечавший за часть «полицейскую», также напрямую доносил обо всех беспорядках Д.П. Руничу. Нарушение прерогативы университетского Совета в отношении надзора за студентами было следствием размытости формулировок о пределах власти попечителя в университетском законодательстве, а также связано и с состоянием столичного университета, так и не получившего собственного устава.

При «разборе» студентов Д.П. Рунич руководствовался собственными соображениями о целесообразности исключения или оставления в университете, перевода в магистры благонадежных студентов. Д.П. Рунич категорично писал министру А.Н. Голицыну, обнаруживая желание показать меру «неустройств» в университете по вине предшественника - С.С. Уварова: «О нравственности студентов не могу к прискорбию сделать выгодного отзыва... <..> ...Самые грубейшие пороки допущены по причине худого надзора за студентами и неограниченной свободы, которой предоставлено было им пользоваться» $[8$, л. 5]. Результаты «разбора» студентов были впоследствии пересмотрены в министерстве, но система управления, при которой право судить об учащихся и их поведении отнималось у ученой корпорации и присваивалось чиновникам, утвердилась надолго. Тот же директивный стиль отличал М.Н. Мусина-Пушкина, руководившего столичным учебным округом в $1845-1856$ годах.

Изменения в системе дисциплинарного контроля назрели в 1830-х гг. по мере увеличения численности студентов, большинство из которых теперь составляли своекоштные студенты-дворяне, жившие вне стен университета (см. подробнее: [7, с. 195-232]). Управление растущей разнородной массой студентов требовало выработки единообразных и законодательно закрепленных норм, которые содержались в Уставе 1835 г., дополнялись официальными «Правилами для студен- тов» и подробными инструкциями инспектору студентов. Инспектор более не выбирался из профессоров, а назначался попечителем из лиц, не принадлежавших к университетскому сообществу. У него было несколько помощников, в обязанности которых входило наблюдение за студентами вне аудиторий. Так, в мае 1839 г. в Петербургском университете было положено ввести в штат четыре субинспектора [13, л. 16].

При новом режиме контроля нравственность студентов осталась залогом их формальных успехов. Право на льготы по оплате обучения или получение казенной стипендии мотивировало студента не только к усердной учебе, но и к осмотрительному поведению.

Среди причин взысканий, которым подвергались студенты Петербургского университета второй половины $1830-\mathrm{x}$ - начала 1850-х гг., чаще всего фигурировали несоблюдение формы, предписанных внутренних правил, а также общественного «благочиния и благоустройства». Другую группу составляли взыскания за нарушения по учебной части: за неявку на лекцию или экзамен, за посещение утреннего спектакля во время лекций и т. п. В то же время получить представление о численности подвергшихся дисциплинарному взысканию за тот или иной промежуток времени по делопроизводственным документам невозможно. Встречаются дела, отражающие отдельные инциденты, получившие общественную огласку или привлекшие внимание императора. В ежегодных университетских отчетах, где была представлена основная университетская статистика, фиксировалось только число студентов, по разным причинам отчисленных из учебного заведения. Этим отчетам придавалось значение репрезентаций, они не должны были уронить репутацию университета в глазах министерства и публики, поэтому проступки студентов не могли в них отражаться. Поведение студентов, замеченных в мелких нарушениях правил, в итоговом аттестате все равно квалифицировалось языком университетского законодательства как «довольно хорошее».

Инспектор после 1835 г. выполнял лишь наблюдательную функцию, сообщая о дисциплинарных проступках напрямую попечителю учебного округа, который определял меру на- 
казания студента в серьезных случаях, в менее серьезных это решал ректор. Властные полномочия инспектора существенно отличались от тех, которыми наделялись инспекторы-профессора в первой трети XIX в., сами определявшие серьезность проступка студента и вид наказания, обращаясь к Конференции только в случаях, требующих коллегиального решения (исключение, отдача в солдаты, что, в свою очередь, согласовывалось с попечителем и министром народного просвещения). За нарушение формы или режима инспектор мог своей властью наказать студента однодневным карцером, но эти эпизоды отражены лишь в мемуарных источниках.

Разбор студенческих проступков мог дойти до императора, и таких дел по столичному университету встречается достаточно. В этом случае профессорская коллегия почти не имела возможностей влиять на исход дела, и нередко оно заканчивалось для студента исключением из университета. Продолжить обучение впоследствии он мог только по личному прошению на имя министра. Но, как свидетельствуют архивные материалы, к студентам дворянского происхождения могло быть применено смягчение наказаний. Вместо исключения такой студент отчислялся из университета "по собственному желанию», что давало ему право продолжить обучение в другом университете [17].

Инструкция инспектору, изданная в 1837 г., предписывала следить, чтобы «студенты ни под каким предлогом и названием не заводили тайных обществ и сходбищ» [9, стб. 123], имея в виду контроль за политической благонадежностью и общественными связями студентов. Инспектор должен был также противодействовать любым проявлениям студенческой корпоративной культуры и процессу объединения учащихся в кружки, товарищества, дружеские и земляческие группы $[27$, p. 167]. В особых случаях, обычно по распоряжению министра или по Высочайшему повелению, за студентом мог быть установлен индивидуальный надзор как в университете, так и за его пределами. При малейшем подозрении в политической неблагонадежности, поводом к которому мог быть и анонимный донос от постороннего университету лица, начальство исключало такого студента [18].
Воспитание политической лояльности дополнялось контролем за содержанием преподавания [26, р. 30].

При всей суровости законодательства личные качества инспектора определяли меру его взыскательности в каждом конкретном случае. В университетской мемуаристике имеются свидетельства о чрезмерной строгости инспекторов, из-за которой учеба в университете превращалась в хронику противостояния «педелям». Студенческий протест против неуместной строгости инспекции носил коллективный характер и выражался как в мелких каверзах, так и в способах держать соглядатая в постоянном напряжении, не нарушая внешнего повиновения. Острые конфликты такого рода отмечены мемуаристами Казанского и Московского университетов.

В Петербургском университете случаев студенческих обструкций в отношении инспекторов, которые бы документально подтверждались, не встречается. Мемуаристы-универсанты 1830-1840-х гг., несмотря на упоминания о стеснительных правилах, столкновениях с попечителем и даже наказаниях, с особой теплотой вспоминают инспекторов И.П. Филиппова и А.И. Фицтума фон Экштедта. Последний был назначен в университет в 1839 г. и служил в своей должности до студенческих волнений 1861 года. Ведомственные документы свидетельствуют о том, что А.И. Фицтум фон Экштедт в конфликтных ситуациях часто защищал студентов и избегал представления на них компрометирующих материалов. Так, после доноса бывшего студента польского происхождения на своих товарищей о том, что они распространяют запрещенные книги, инспектору было рекомендовано усилить контроль за студентами польского происхождения. Однако он уверил попечителя в том, что имеющегося наблюдения достаточно и что «не было замечено между студентами, в особенности польского происхождения, развития демократических мыслей», как не найдено и запрещенных книг [20, л. 27]. Эта властная девиация - готовность «надзирать» и нежелание «наказывать» - свидетельствует о том, что, будучи отставным полковником, героем польской войны 1831 г. и имея прямой доступ к попе- 
чителю, А.И. Фицтум фон Экштедт за годы службы в университете связал себя рамками «корпоративной солидарности» с его младшими членами не меньше, чем университетские профессора.

Мемуаристы вспоминают о том, что А.И. Фицтум фон Экштедт с отеческой заботой советовал им, как поступить в случае конфликта с профессором, а также вежливо просил сбрить усы, привести в порядок мундир, без донесения об этом начальству. Смягчал он даже конфликты, вызванные придирками к студентам после их неожиданных встреч с императором на улицах Петербурга [15, с. 572].

Помимо надзора и постоянного присутствия в университете в учебное время А.И. Фицтум фон Экштедт активно участвовал в культурной жизни и складывающейся системе взаимопомощи студентов. В доме инспектора устраивались благотворительные музыкальные вечера с участием знаменитостей, куда приглашались воспитанницы Патриотического и Екатерининского институтов. Сборы с концертов передавались наиболее нуждающимся студентам.

Не менее известными в городе были литературные вечера по средам у ректора П.А. Плетнева. В нижнем этаже ректорского флигеля он устроил что-то вроде гостиной, куда приглашались студенты и профессора [25]. Сама обстановка встреч в доме ректора «воспитывала», прививала хороший вкус и манеры, эти встречи вписывались в сценарий собраний «большой университетской семьи». Таким образом, патриархальный стиль взаимодействия, когда профессора относились к студентам не как к младшим коллегам, а как к воспитанникам, в Петербургском университете прослеживается и во второй половине 1830-1840-х годов. Формализованные рамками управления и обучения отношения универсантов бюрократизируются, но неформальные связи удерживаются в рамках «семейного стиля».

Со второй половины 1850 -х гг. с развитием студенческой корпоративности и общественной активности наступает перелом в отношениях студентов и университетского начальства. Растущее увлечение студентов политикой в годы общественного подъема и подготовки «великих реформ», а также невозможность ограничить студенческую актив- ность прежними формами полицейского надзора и наказаний или «патриархальной» солидарности всех со всеми предопределили нарастание конфронтации между студенчеством и администрацией университета.

Результаты. В целом на примере истории столичного университета Российской империи и его предшественника (Педагогического института) можно заключить, что на протяжении дореформенного периода истории столичного университета происходила постепенная трансформация системы надзора за студентами - от мягкого «домашнего» присмотра к серьезному полицейскому и идеологическому надзору. Тем не менее черты «патриархальности» сохранялись в рамках неформального общения внутри университетского сообщества Петербургского университета вплоть до 1861 года. Изменение форм надзора и правовых рамок пребывания студентов в университете отражалось в нормативных актах, ведомственных документах и университетском делопроизводстве, а также в самой полицейской практике. Необходимость усиления нравственно-полицейского надзора за студентами связывалась не только с увеличением их численности, но и с изменением форм обучения в университете в пользу все большей открытости, конкурентности и публичности, а также с притоком в университет польских уроженцев и представителей дворянской элиты, многие из которых обучались за собственный счет и претендовали на большую независимость.

\section{ПРИМЕЧАНИЕ}

1 Работа выполнена в рамках государственного задания Федерального исследовательского центра «Кольский научный центр Российской академии наук» (№ 0226-2019-0066 «Социокультурное и научно-техническое развитие северо-западной части Арктической зоны РФ в XIX-XX вв.: исторический и антропологический ракурсы»).

The reported study was carried out in the framework of the state task of the Federal Research Centre "Kola Science Centre of the Russian Academy of Sciences” (№ 0226-2019-0066 "Sociocultural and Scientific-Technical Development of the Northwestern Part of the Arctic Zone of the Russian Federation in the 19-20 $0^{\text {th }}$ Centuries: Historical and Anthropological Focus"). 


\section{СПИСОК СОКРАЩЕНИЙ}

РГИА - Российский государственный исторический архив.

РО ИРЛИ - Рукописный отдел Института русской литературы РАН.

ЦГИА СПб - Центральный государственный исторический архив г. Санкт-Петербурга.

\section{СПИСОК ЛИТЕРАТУРЫ}

1. Андреев, А. Ю. Российские университеты XVIII - первой половины XIX века в контексте университетской истории Европы / А. Ю. Андреев. М. : Знак, 2009. -640 с.

2. Буслаев, Ф. И. Мои воспоминания / Ф.И.Буслаев // Московский университет в воспоминаниях современников. - М. : Современник, 1989. - С. 200-222.

3. Виттекер, Ц. Х. Граф Сергей Семенович Уваров и его время / Ц. Х. Виттекер. - СПб. : Акад. проект, 1999. - $350 \mathrm{c.}$

4. Вишленкова, Е. А. Казанский университет Александровской эпохи: альбом из нескольких портретов / Е. А. Вишленкова. - Казань : Изд-во Казан. гос. ун-та, 2003. $-240 \mathrm{c}$.

5. Вишленкова, Е. А. «Воспроизводство себе подобных» в российском университете первой половины XIX века / Е. А. Вишленкова, К. А. Ильина. - М. : НИУ ВШЭ, 2011. -52 с.

6. Жуковская, Т. Н. Петербургский университет в городском пространстве первой трети XIX в. / Т. Н. Жуковская // Социальная история. Ежегодник. 2009 / отв. ред. Н. Л. Пушкарева. - СПб. : Алетейя, 2010. - С. 41-67.

7. Жуковская, Т. Н. Anima universitatis: студенчество Петербургского университета в первой половине ХІХ века / Т. Н. Жуковская, К. С. Казакова. М. : Новый хронограф. -543 с.

8. Записка о настоящем положении СанктПетербургского университета // РО ИРЛИ. -Ф. 263. Оп. 3. - Д. 50. -54 л.

9. Инструкция инспектору студентов Императорского Санкт-Петербургского университета // Сборник распоряжений по Министерству народного просвещения. В 16 т. Т. 2. 1835-1849. - СПб. : Тип. Императ. Акад. наук, 1866. - Стб. 121-134.

10. Кулакова, И. П. Университетское пространство и его обитатели. Московский университет в историко-культурной среде XVIII века / И. П. Кулакова. - М. : Новый хронограф, 2006. - 333 с.

11. Марголис, Ю. Д. «Единым вдохновением». Из истории Петербургского университета в конце XVIII - первой половины XIX в. / Ю. Д. Марголис, Г. А. Тишкин. - СПб. : Изд-во СПбГУ, 2000. $222 \mathrm{c}$.
12. Об умопомешательстве студента Мальцева // ЦГИА СПб. - Ф. 13. - Оп. 1. - Д. 359 - 32 л.

13. Об усилении надзора за студентами университета и о расширении штата лиц, занимающихся этим надзором // РГИА. - Ф. 733. - Оп. 22. Д. $65 .-18$ л.

14. Об утверждении списков студентов, избранных старшими в комнатах // ЦГИА СПб. - Ф. 13. Оп. 1. - Д. 524. -9 л.

15. Оже де Ранкур, Н. Ф. В двух университетах : Воспоминания. 1837-1843 / Н. Ф. Оже де Ранкур // Русская старина. - 1896. - Т. 86, № 6. - С. 571-582.

16. О наказании студентов розгами // ЦГИА СПб. -Ф. 13.-Оп. 1.-Д. 189. - 7 л.

17. О происшествии, случившемся 4 октября вечером на Невском проспекте со студентом Мессингом и об увольнении из университета студента Соца // ЦГИА СПб. - Ф. 139. - Оп. 1. - Д. 4919. - 15 л.

18. О студенте Петербургского университета Александре Толстове // РГИА. - Ф. 735. - Оп. 10. Д. 223. - 27 л.

19. Отчеты и предложения смотрителя об улучшении поведения студентов // ЦГИА СПб. - Ф. 13. Оп. 1. - Д. 205. -27 л.

20. По отношению князя Варшавского о существующем между студентами Петербургского университета демократическом образе мыслей // РГИА. - Ф. 735. - Оп. 10. - Д. 167. - 196 л.

21. Рапорты проф. П.Д. Лодия // ЦГИА СПб. Ф. 13. - Оп. 1. - Д. 1061. - 25 л.

22. Санкт-Петербургский университет в первое столетие его деятельности. Материалы по истории СПб. университета. 1819-1919. Т. 1. 1819-1835. -Пг. : 2-я гос. тип., 1919. - 760 с.

23. Университет в Российской империи XVIII первой половины XIX века / под общ. ред. А. Ю. Андреева, С. И. Посохова. - М. : РОССПЭН, 2012. -671 с.

24. Циркулярное предложение о поручении своекоштных студентов университетов полицейскому надзору // Сборник распоряжений по Министерству народногопросвещения. В 16 т. Т. 1. 1802-1834.-СПб. : Тип. Императ. Акад. наук, 1866. - Стб. 607-608.

25. Шубин, В. Ф. Вечера Плетнева в ректорском флигеле / В. Ф. Шубин // Очерки по истории С.-Петербургского университета. Вып. 5. - Л. : Изд-во ЛГУ, 1984. - С. 86-93.

26. Friedman, R. Masculinity, Autocracy and the Russian University. 1804-1863 / R. Friedman. - N. Y. : Palgrave Macmillan, 2005. - 195 p.

27. Kazakova, K. S. From St. Petersburg to Dorpat and Back: On Academic Migrations and Communications Between Universities in the First Half of the $19^{\text {th }}$ Century / K. S. Kazakova, T. N. Zhukovskaya // Acta Baltica Historiae et Philosophiae Scientiarum. 2018. - Vol. 6, № 2. - P. 162-171. - DOI: 10.11590/ abhps.2018.2.10. 


\section{REFERENCES}

1. Andreev A.Yu. Rossiyskie universitety XVIII-pervoy poloviny XIX veka v kontekste universitetskoy istorii Evropy [Russian Universities of the $18^{\text {th }}-$ First Half of the $19^{\text {th }}$ Century in the Context of European University History]. Moscow, Znak Publ., 2009. 640 p.

2. Buslaev F.I. Moi vospominaniya [My Memories]. Moskovskiy universitet v vospominaniyakh sovremennikov [Moscow University in the Memoirs of Contemporaries]. Moscow, Sovremennik Publ., 1989, pp. 200-222.

3. Vitteker Ts.Kh. GrafSergey Semenovich Uvarov i ego vremya [Count Sergey Semenovich Uvarov and His Time]. Saint Petersburg, Akademicheskiy proekt Publ., 1999.350 p.

4. Vishlenkova E.A. Kazanskiy universitet Aleksandrovskoy epokhi: albom iz neskolkikh portretov [Kazan University of the Alexander Epoch: An Album of Several Portraits]. Kazan, Izd-vo Kazanskogo gosudarstvennogo universiteta, 2003. 240 p.

5. Vishlenkova E.A. Ilyina K.A. «Vosproizvodstvo sebe podobnykh» $v$ rossiyskom universitete pervoy poloviny XIX veka [Reproduction of Their Own Kind at a Russian University in the First Half of the $19^{\text {th }}$ Century]. Moscow, NIUVShE, 2011.52 p.

6. Zhukovskaya T.N. Peterburgskiy universitet $\mathrm{v}$ gorodskom prostranstve pervoy treti XIX v. [Petersburg University in the Urban Space of the First Third of the $19^{\text {th }}$ Century]. Pushkareva N.L., ed. Sotsialnaya istoriya. Ezhegodnik. 2009 [Social History. Yearbook. 2009]. Saint Petersburg, Aleteya Publ., 2010, pp. 41-67.

7. Zhukovskaya T.N., Kazakova K.S. Anima universitatis: Studenchestvo Peterburgskogo universiteta $v$ pervoy polovine XIX veka [Anima universitatis: Students of Petersburg University in the First Half of the $19^{\text {th }}$ Century]. Moscow, Novyy khronografPubl., 2018. 543 p.

8. Zapiska o nastoyashchem polozhenii SanktPeterburgskogo universiteta [Note on the Current Situation of St. Petersburg University]. RO IRLI [Manuscript Department of the Institute of Russian Literature], F. 263, Op. 3, D. 50. 5411.

9. Instruktsiya inspektoru studentov Imperatorskogo Sankt-Peterburgskogo universiteta [Instructions to the Superintendent of Students of Imperial St. Petersburg University]. Sbornik rasporyazheniy po Ministerstvu narodnogo prosveshcheniya. V16t. T. 2. 1835-1849 [Collection of Decrees on the Ministry of Public Education. In 16 Vols. Vol. 2. 1835-1849]. Saint Petersburg, Tipografiya ImperatorskoyAkademii nauk, 1866, cols. 121-134.

10. Kulakova I.P. Universitetskoe prostranstvo $i$ ego obitateli. Moskovskiy universitet v istoriko- kulturnoy srede XVIII veka [University Space and Its Inhabitants. Moscow University in the Historical and Cultural Environment of the $18^{\text {th }}$ Century]. Moscow, Novyy khronograf Publ., 2006. 333 p.

11. Margolis Yu.D., Tishkin G.A. "Edinym vdokhnoveniem». Ocherki istorii universitetskogo obrazovaniya $v$ Peterburge v kontse XVIII - pervoy polovine XIX v. ["In One Inspiration." Essays on the History of University Education in Saint Petersburg in the Late $18^{\text {th }}-$ First Half of the $19^{\text {th }}$ Century]. Saint Petersburg, Izd-vo SPbGU, 2000. 222 p.

12. Ob umopomeshatelstve studenta Maltseva [On the Insanity of Student Maltsev]. TsGIA SPb [Central State Historical Archive of Saint Petersburg], F. 13, Op. 1, D. 359. 321.

13. Ob usilenii nadzora za studentami universiteta i o rasshirenii shtata lits, zanimayushchikhsya etim nadzorom [On Strengthening Supervision of University Students and on Expanding the Staff of Persons Involved in This Supervision]. RGIA [Russian State Historical Archive], F. 733, Op. 22, D. 65. 181.

14. Ob utverzhdenii spiskov studentov, izbrannykh starshimi v komnatakh [On the Approval of the Lists of Students Elected by the Elders in the Rooms]. Ts GIA SPb [Central State Historical Archive of Saint Petersburg], F. 13, Op. 1, D. 524. 91.

15. Ozhe de Rankur N.F. V dvukh universitetakh: Vospominaniya. 1837-1843 [In Two Universities. Memoirs. 1837-1843]. Russkaya starina, 1896, vol. 86, no. 6. pp. 571-582.

16. O nakazanii studentov rozgami [About Punishing Students with Rods]. Ts GIA SPb [Central State Historical Archive of Saint Petersburg], F. 13, Op. 1, D. 189. 71.

17. O proisshestvii, sluchivshemsya 4 oktyabrya vecherom na Nevskom prospekte so studentom Messingom i ob uvolnenii iz universiteta studenta Sotsa [About the Incident That Happened on October 4 in the Evening on Nevsky Prospect with Student Messing and About the Dismissal of Student Sots from the University]. TsGIA SPb [Central State Historical Archive of Saint Petersburg], F. 139, Op. 1, D. 4919.151.

18. O studente Peterburgskogo universiteta Aleksandre Tolstove [About Student of Petersburg University Alexander Tolstov]. RGIA [Russian State Historical Archive], F. 735, Op. 10, D. 223. 271.

19. Otchety i predlozheniya smotritelya ob uluchshenii povedeniya studentov [Reports and Suggestions of the Supervisor on Improving Students' Behavior]. Ts GIA SPb [Central State Historical Archive of Saint Petersburg], F. 13, Op. 1, D. 205. 271.

20. Po otnosheniyu knyazya Varshavskogo o sushchestvuyushchem mezhdu studentami Peterburgskogo universiteta demokraticheskom obraze mysley [Regarding Prince Varshavsky About the 
Democratic Way of Thinking Existing Between Students of St. Petersburg University]. RGIA [Russian State Historical Archive], F. 735, Op. 10, D. 167. 1961.

21. Raporty prof. P.D. Lodiya [Reports of Professor P.D. Lodia]. Ts GIA SPb [Central State Historical Archive of Saint Petersburg], F. 13, Op. 1, D. 1061. 251.

22. Sankt-Peterburgskiy universitet $v$ pervoe stoletie ego deyatelnosti. Materialy po istorii SPb. universiteta. 1819-1919. T. 1. 1819-1835. [St. Petersburg University in the First Century of Its Activity. Materials on the History of St. Petersburg. University. 1819-1919. Vol. 1. 1819-1835]. Petrograd, 2-ya gosudarstvennaya tipografiya, $1919.760 \mathrm{p}$.

23. Andreev A.Yu., Posokhov S.I., eds. Universitet $v$ Rossiyskoy imperii XVIII - pervoy poloviny XIX veka [University in the Russian Empire of the $18^{\text {th }}-$ First Half of the $19^{\text {th }}$ Century]. Moscow, ROSSPEN Publ., 2012.671 p.

24. Tsirkulyarnoe predlozhenie o poruchenii svoekoshtnykh studentov universitetov politseyskomu nadzoru [Circular Proposal on the Assignment of Self-
Supporting University Students to Police Supervision] Sbornik rasporyazheniy po Ministerstvu narodnogo prosveshcheniya. V16 t. T. 1. 1802-1834 [Collection of Decrees on the Ministry of Public Education. In 16 Vols. Vol. 1. 1802-1834]. Saint Petersburg, Tipografiya Imperatorskoy Akademii nauk, 1866, pp. 607-608.

25. Shubin V.F. Vechera Pletneva v rektorskom fligele [Evenings of Pletnev in the Rector's Wing]. Ocherki po istorii S.- Peterburgskogo universiteta. Vyp. 5 [Essays on the History of St. Petersburg University. Iss. 5]. Leningrad, Izd-vo LGU, 1984, pp. 86-93

26. Friedman R. Masculinity, Autocracy and the Russian University. 1804-1863. New York, Palgrave Macmillan, 2005. $195 \mathrm{p}$.

27. Kazakova K.S. Zhukovskaya T.N. From St. Petersburg to Dorpat and Back: On Academic Migrations and Communications Between Universities in the First Half of the $19^{\text {th }}$ Century. Acta Baltica Historiae et Philosophiae Scientiarum, 2018, vol. 6, no. 2, pp. 162-171. DOI : 10.11590/abhps.2018.2.10.

\section{Information About the Authors}

Ksenia S. Kazakova, Candidate of Sciences (History), Senior Researcher, Barents Centre of the Humanities, FRC "Kola Science Centre of the Russian Academy of Sciences", Akademgorodok, 40-A, 184209 Apatity, Russian Federation, Ksenia-kuznec@yandex.ru, https://orcid.org/0000-0002-5071-4947

Tatyana N. Zhukovskaya, Candidate of Sciences (History), Associate Professor, Department of Russian History from Ancient Times to the $20^{\text {th }}$ Century, Institute of History, St. Petersburg University, Mendeleevskaya Liniya, 5, 199034 Saint Petersburg, Russian Federation, tzhukovskaya@yandex.ru, https://orcid.org/0000-0001-9776-0038

\section{Информация об авторах}

Ксения Сергеевна Казакова, кандидат исторический наук, старший научный сотрудник, Центр гуманитарных проблем Баренц региона ФИЦ «Кольский научный центр Российской академии наук», Академгородок 40-A, 184209 г. Апатиты, Российская Федерация, Kseniakuznec@yandex.ru, https://orcid.org/0000-0002-5071-4947

Татьяна Николаевна Жуковская, кандидат исторических наук, доцент кафедры истории России с древнейших времен до XX в., Институт истории, Санкт-Петербургский государственный университет, Менделеевская линия, 5, 199034 г. Санкт-Петербург, Российская Федерация, tzhukovskaya@yandex.ru, https://orcid.org/0000-0001-9776-0038 